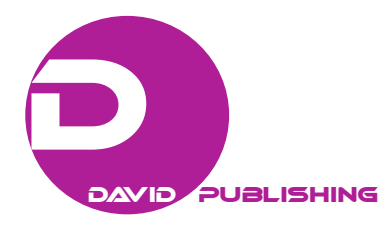

\title{
Destination Governance for Sustainable Tourism
}

\author{
Simona Franzoni \\ University of Brescia, Brescia, Italy
}

\begin{abstract}
The tourism system is characterised by the number of actors (public, profit, and non-profit organisations) with specific expectations, roles, and responsibilities. The actors play a significant role in the territory: they need the efforts of inter-institutional cooperation and to develop a network in order to contribute, in relation to the type of interaction carried out, to the economic development and to increasing competitiveness and tourism labor market. In this article, the author suggests a conceptual framework allowing attaining a governance model of the tourism system aimed at enhancing the relationships with the various relevant actors in order to achieve common goals based on sustainable performance.
\end{abstract}

Keywords: destination governance, network structure, network management, sustainability

\section{Introduction}

The actual tourism scenario is characterised by the following themes: the need for an effective integration between public and private tourism organisations in the governance of the territory while preserving the sustainability of the community; the competitiveness and the alliances of the tourism industry; the relationships between the actors involved and the mechanisms of coordination among them as well as the consistency of the tourist destinations.

The tourist destinations are thought of as precise geographical areas in which the tourism organisations (travel agencies, tour operators, hotels, restaurants, etc.), local public authorities (public transport, information points, etc.), third sector (tourism cooperatives, cultural associations, etc.) that are present attempt to make the areas more attractive by highlighting the value of the countryside as well as the local social, artistic, and cultural traditions. In this sense, the tourist destination becomes a network of relations between all of the actors both public and private that are involved in it.

In tourism, the approach of the study from the perspective of the network has first of all a long and established tradition (Pavlovich, 2003; Scott, Cooper, \& Baggio, 2008).

Effective tourist destinations represent strong public-private partnerships where the public administrations, in terms of public governance (Bovaird \& Loffler, 2004; Osborne, 2010; Rhodes, 2000), play a primary role in the complex function of guiding the processes of development of territories (Madanipour, Hull, \& Healey, 2001; Rigall-Torrent, 2008; Shaw \& Williams, 2004). The competitiveness of a tourist destination is not measured at the level of a single organisation but rather in the capacity of the operators involved in tourism to bring their forces together at the level of the destination itself. Therefore, the tourism system needs a model of governance where the system of decisions and actions aimed at consolidating and growing the sustainability of the territory

Simona Franzoni, associate professor, Department of Economics and Management, University of Brescia. Email: simona.franzoni@unibs.it. 
and its destination by defining clear and shared objectives, actions, and results for development between the private and public operators involved (travel agencies, tour operators, tourism firms, local public authorities, tourism cooperatives, cultural associations, etc.).

In this article, the author suggests a conceptual framework allowing attaining a governance model of the tourism system aimed at enhancing the network of relationships with the various relevant actors in order to create, maintain, and develop sustainable tourist destinations where public and private organisations work together to achieve common goals. These include the enrichment and attractiveness of the territories and their destinations, through appropriate integration of the expectations of tourists, the local community, and the enterprises that are part of it.

\section{Theoretical Framework}

The tourism system needs a new paradigm of governance aimed at making the most of the network of relations with the different relevant actors: a governance model that is able to create a shared vision of development, to influence the social forces of a community and manage a network. According to Provan and Kenis (2008, p. 231), the network is "a group of three or more legally autonomous organisations that work together to achieve not only their own goals but also a collective goal".

A tourist destination founded on a network is characterised by the involvement of a broad and heterogeneous group of actors (public administration, firm, non-profit organisation, etc.) where each relevant actor covers a well-defined role both in terms of the contribution it makes as well as the expectations it creates in the territory (territorial areas characterised by an integrated offer of cultural, environmental, and tourism attractions, including typical products of agriculture and local artisan production). According to Laws (1995, p. 9), the destination can be expressed in "a group of actors brought together through relationships with specific rules, where the action of each individual influences others, meaning that common objectives must be defined and obtained in a coordinated way”. Therefore, the tourist destination is a network of key stakeholders, directly or indirectly, involved in the co-design and co-production of goods and services (Dredge, 2006; Lemmetyinen \& Go, 2009; Kenis \& Provan, 2009; Paget, Dimanche, \& Mounet, 2010; Klijn, Steijn, \& Edelenbos, 2010).

According to the UNWTO (2004), the potential stakeholders in tourism at local destinations can be represented as follows: communities, public sector, private sector, non-profit sector, tourists (organisations representing tourists' interests).

The ability to satisfy the stakeholders' needs is realized through the development of a governance system that is able to bring together the contributions and influence the behavior of the different actors towards common goals. As well as this, the application of a governance model could allow autonomous organisations that are part of the network to gain notable benefit in terms of rationalization of the use of their resources as well as helping them achieve economies of scale and economies of learning which are linked to the principles of sustainability. According to Provan and Kenis (2008, p. 3), "the advantages of network, coordination in both public and private sectors, are considerable, including enhanced learning, more efficient use of resources, increased capacity to plan for and address complex problems, greater competitiveness, and better services for clients and customers” (Alter \& Hage, 1993; Huxham \& Vangen, 2005).

Therefore, the adoption of a new governance model of tourist destinations could represent the best way of guarding the autonomy of the single organisations and at the same time, creating synergies. Who leads the tourist destination has the responsibilities to interact positively with all the actors of the system through the 
processes of coordination and integration aimed at creating consensus, sharing, and promoting convergence of interests on problems expectations and solutions, while also stimulating the development of concrete services which are in line with the needs of the tourist. Who directs the tourist destination has the role to favour decision-making processes between the different actors that take part, each one with a different role and influence through the activation and the incentive of exchange of decisions among the different public actors (local public authorities, regions, etc.), profit actors (tourist firms, travel agencies, etc.), and non-profit actors (cultural associations, tourism cooperatives, etc.).

Given the interrelationship between the interests of the public, private, and non-profit participants in offering tourism services, a new concept of governance (see Figure 1), i.e., destination governance, is proposed. The term "destination governance", in general, refers to a system through which the various organisations relate to each other and their stakeholders in a tourist destination; but it also refers to the integrated management of the services and the activities in the tourism sector developed by the actors of the network to optimize the sustainable performance of: the territory, the destination, and the autonomous organisations involved. Actors linked to each other through relations, connections, and integrated processes of governance (planning, control, assessment, and accountability), in order to facilitate the overall effectiveness of the system of the tourism services offered by the various actors involved in the destinations.

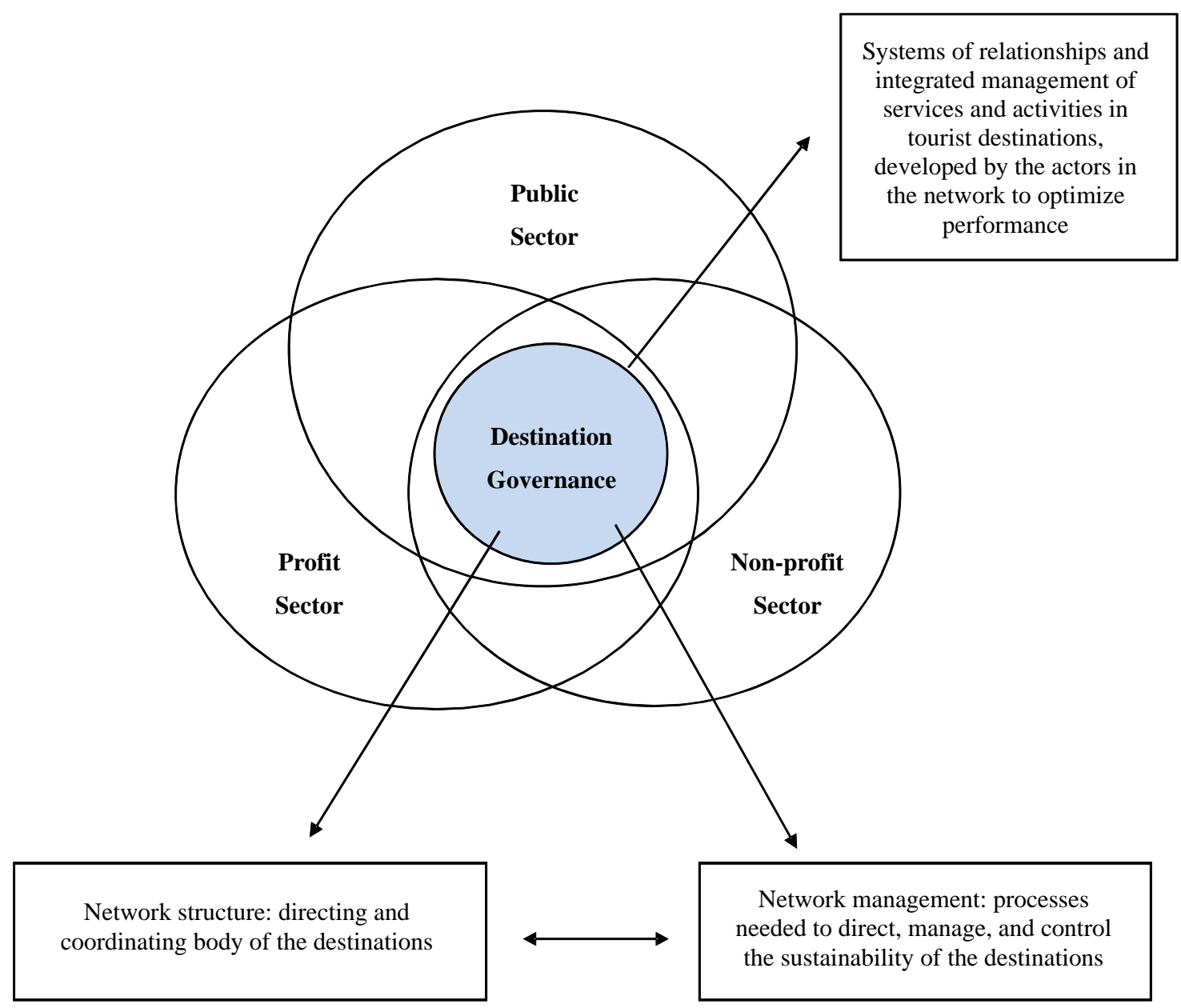

Figure 1. Destination governance. 
Destination governance implies the following dimensions (Franzoni, 2014):

(1) The structural dimension: "the network structure";

(2) The process and result dimension: "network management".

\section{The Network Structure}

The structure of the network (Provan \& Milward, 2001) represents the body responsible for the governance by a logic of coordination and integration as well as the development of a system of interventions in response to the tourists' needs.

Provan and Kenis (2008) and Kenis and Provan (2009) have demonstrated that network governance can have different forms according to the actors involved. In particular, these authors identify the following types (see Figure 2):

(1) Shared governance form: There is not a distinct governance body and multiple actors work collectively;

(2) Lead organisation form: There is a lead organisation that provides administration for the network and/or facilitates the members' activities to pursue common goals;

(3) Network administrative form: There is a network administrative organisation that is a separate administrative entity to coordinate, manage, and sustain the network.

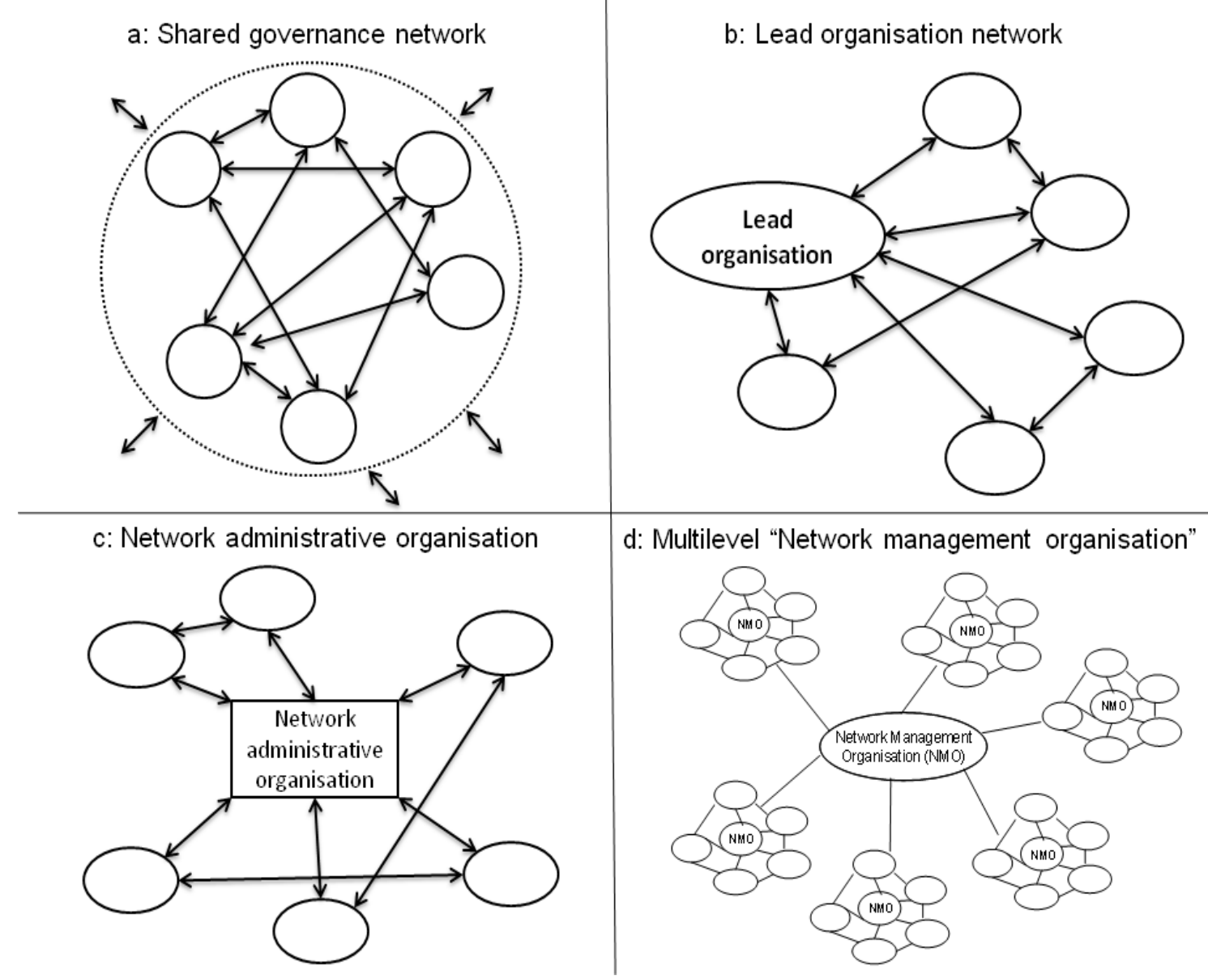

Figure 2. Form of network governance. Source: Adaptation of Figure 1 of Kenis and Provan (2009). 
In the tourism sector, the first configuration could be defined as "point-to-point" (Rispoli \& Tamma, 1995). The tourism product is aggregated through a collection of single relationships with the different actors in the tourist destination. The unity and coherence of the product is completely managed by the tourist who, according to his/her preferences and the information available, assembles the different factors of attraction.

The second configuration could be defined as a "corporate destination”, according to Bieger (1997) and Flagestad and Hope (2001). Here, the tourism offer is planned, managed, and promoted by a key player such as a specialised tourist firm, international tour operator who through direct ownership or contractual forms controls the majority according to the example of the attractive factors, the tourism structures and infrastructure. The management of the tourist destination is present in a centralized form with an integrated hierarchy and can benefit from unity of command and rapid decision-making as well as a defined strategy.

The third configuration could be defined as a "destination community" (Martini, 2005) where the ownership, the control of the resources, and the tourism activities are split among many actors who display a diverse range of specialisations which are interdependent but autonomous. The local public institutions take on a relevant administrative role in promoting and sustaining the tourism development.

Alongside the three proposed by Provan and Kenis (2008), who stimulate to develop a new theory about network governance, a fourth form can be discerned: "network management organisation" (NMO) (Franzoni, 2013).

More precisely, the network structure of the destination governance could be entrusted to the "NMO", entity of direction and coordination of the network, the structure of which can be influenced by the principles and rules that are in use in different countries. In the tourism sector, the fourth configuration could be defined as "Destination Management Organisation" (DMO).

Why a network can improve the competitive capacity of its components? It is necessary to have strong roles of higher-level governance, able to express a vision to develop the network, define the medium-long-term strategic objectives, and manage relationships and the contributions of participants in the network effectively.

All tourist destinations that are created in order to achieve improvements in the territory are coordinated by the DMO to avoid overlap and redundancies of roles, functions, and activities. In a territory, the number of tourist destinations depends on the attractiveness of this territory and on the level of sustainability expected (Dredge, 1999).

The DMO of a territory could be composed of important public and private actors with a high level of competence and which is capable of leading all of the actors involved in the network to pursue performance of sustainability expected by the territory, the destinations, and the organisations that are operating in this context.

In general, DMO has the following tasks: firstly, to direct and guide with an approach of cooperation and integration, where the ability to create consensus, sharing, and convergence of interests around proposed solutions is essential and critical to success; secondly, to develop a network by coordinating services and interventions in order to achieve the sustainability of the tourist destination.

The single touristic destination presupposes the involvement of all actors with specific professional profiles and competencies that are involved in it, coordinated by entity "second level DMO” (assigned to public or private/profit or non-profit organisations, including monocratic entity) that communicate with the DMO. Therefore, the DMO coordinates all second level DMOs that manage the single destinations: each "second level DMO" coordinates the key actors of each tourist destination. This structure can also be defined as "multilevel DMO”. 
It is the growth and improvement of the operating conditions of the "intermediate bodies" (second level DMO) in the network, the link between the DMO and the autonomous organisations, that constitutes the most important aspect for the future development of the governance of the destinations and makes the top-down and bottom-up communication more rapid, efficient, and effective.

Having said that, it is necessary to underline that the birth of the destination should not lead to the creation of superstructures and the consequent tightening of the system with a consequent increase in overheads. Rather, the approach should be geared towards flexibility, the generation of groups of relevant actors involved in order to achieve strategic objectives and results of benefit to the stakeholders who are directly involved in it and the community at large. Finally, the DMO is responsible for:

(1) Collecting and sharing relevant information based on the needs of the actors;

(2) Facilitating the creation, maintenance, and development of new destinations;

(3) Stimulating the actors of the tourist destinations to participate in the processes of planning, control, assessment, and accountability (network management, fourth paragraph);

(4) Establishing direction of the tourist development of a territory making sure that these directions are shared by "second level DMO" and actors involved in the individual destination;

(5) Motivating "second level DMO" to provide information on the results obtained with evidence of deviations and corrective actions taken;

(6) Assessing the level of achievement of the sustainability results of the territory and the individual tourist destination;

(7) Communicating and sharing the final aggregated results achieved of the territory through the autonomous tourist destinations.

\section{The Network Management}

The second dimension "network management" (Kickert, Klijn, \& Koppenjan, 2001) refers to the decisional processes needed to direct, manage, and control the common goals towards the sustainability performance of the tourist destinations.

The relationship between the network management and the results of the network represents an action of the decision-making processes (Bramwell \& Lane, 2000; Klijn et al., 2010).

The traditional functions of planning, control, assessment, and accountability of the results take on a new meaning, as they relate to the management of resources held by autonomous organisations (Agranoff \& McGuire, 2001; Klijn et al., 2010). Therefore, the network management of the tourism is characterised by processes aimed at:

(1) Directing the activities to achieve results which are consistent with the expectations of the other stakeholders;

(2) Identifying the controls and processes needed to carry out the necessary checks on the reliability of the information and the correctness of the structures and procedures;

(3) Managing the best way for interaction and communication with different types of stakeholders.

In particular, the "second level DMO" will be oriented to guide, coordinate, and control the correct and efficacious transfer in the behaviours at the organisations involved. Each organisation shares what has been agreed and develops its own lines of policy coherent with the indications that have emerged at the level of the tourist destination (second level DMO) and the territory (first level DMO). 
Thus, the network management can be defined as processes of governance and the main objectives of which are: the formulation of strategies at the territory, the development of integrated marketing plans, the development of sustainable services (carried out by the actors involved), and the measurement of the network performance to achieve the final goals of the territory through the single tourist destinations.

Measuring sustainable performance is important for motivating the actors and keeping their attention and support to the network. From an analysis of the literature (Bramwell \& Lane, 2000; Hall \& Lew, 1998; Stabler, 1997; Waligo, Clarke, \& Hawkins, 2013), a shared vision emerges on the need to consider several dimensions and levels of performance of the network, starting from the article of Provan and Milward (2001).

Provan and Milward concentrate on the theme of the evaluation of networks in three analytical dimensions. Firstly, the community (the area which is served by the network), secondly, the network and thirdly, the autonomous organisations that take part in it. More precisely, in the current article, the three dimensions are represented by: the territory (expression in a community and different tourist destinations), the tourist destination (the network of actors involved), and the autonomous organisation (hotel, restaurant, transport enterprise, local public authority, cultural association, etc.), respectively. Overall, the performance affects the evaluation of the costs and benefits of the autonomous organisations, the sustainability as a common goal of the actors involved in the tourist destinations, and the ability to satisfy the expectations of the territory (Klijn et al., 2010; Provan \& Milward, 2001). In order to measure and evaluate tourism performance, a set of indicators can be formulated, based on a thorough review of the relevant literature (Liverman, Hanson, Brown, \& Meredith, 1988; Marsh, 1993; Kuik \& Verbruggen, 1991; Manning, 1999; Vera \& Ivars, 2003; Bossel, 1999; Bloyer, Gustke, \& Leung, 2004; Blackstock, McCrum, Scott, \& White, 2006; White, McCrum, Blackstock, \& Scott, 2006; Franzoni, 2015) and the several initiatives that provide methodological support for the identification of sustainable development indicators (World Travel and Tourism Council, World Tourism Organisation, \& Earth Council, 1995; Global Reporting Initiative, 2002; UNWTO, 2004; OECD, 2013; European Union, 2013) with different levels of aggregation. The World Tourism Organisation affirms the importance of the collection of information by means of a set of indicators, designed to facilitate the processes of planning, programming, managing, measuring, and evaluating the performance. Indicators are an intrinsic component of the planning process and the constant monitoring can lead to continuous improvement - building solutions into management. The use of synthetic indicators should be an essential reference point for improving the decision-making process, ensuring the best possible adaptation between demand and supply of tourism services, and achieving sustainability performance (UNWTO, 2004).

\section{Conclusion}

The model developed would find an effective application and should encourage the sharing of a common vision and purposes among all stakeholders. In this context, each actor, according to its level of importance and defined responsibilities, takes part in the destination governance in order to pursue the sustainable performance, and in general, to participate in the tourist development of community and the economic growth of local, national, and international territories.

The above considerations show, therefore, that the tourism actors need to apply a broader approach that is increasingly oriented towards integration in contexts where tourism organisations operate. The advantages that an individual actor gets by participating in a network are immediately measurable referring to the possibility of sharing investments, exploitation of innovation and technology, containment and rationalization of production costs and the risks involved. 
Cooperation between relevant actors in the tourism system highlights the strategic intent of the organisation to ensure a sustainable future. Therefore, skills and attitudes aimed at developing and promoting positive relationships with stakeholders with whom you share the advantages and/or disadvantages, related to the quality of the results, acquire strategic importance and are essential for economic and social development.

The path towards sustainability will not be short and must involve the main actors in the tourism sector, who must be convinced of the opportunity of sustainability as an important factor in its success. This implies the adoption of an effective model of governance (such as those described above) oriented towards the sustainable development and the constant monitoring and evaluation of performance. The real challenge is to put it into practice and follow it in a manner that is determined and convinced in order to have success in the social-environmental, economies and competitiveness at the level of: the territory, the destination, and the autonomous organisations involved.

\section{References}

Agranoff, R., \& McGuire, M. (2001). Big questions in public network management research. Journal of Public Administration Research and Theory, 11(3), 295-326.

Alter, C., \& Hage, G. (1993). Organizations working together. Newbury Park, CA: Sage Publications.

Bieger, T. (1997). Management von Destinationen und Tourismusorganisationen. Wien: Oldenburg.

Blackstock, K. L., McCrum, G., Scott, A., \& White, V. (2006). A framework for developing indicators of sustainable tourism. Aberdeen: Macaulay Institute.

Bloyer, J., Gustke, L., \& Leung, Y. (2004). Indicators for sustainable tourism development: Crossing the divide from definition to actions. In F. Pineda, C. Brebbia, \& M. Múgica (Eds.), Sustainable tourism (pp. 109-115). Southampton: WiT.

Bossel, H. (1999). Indicator for sustainable development: Theory, method, applications. Manitoba, Canada: International Institute for Sustainable Development.

Bovaird, T., \& Loffler, E. (2004). Public management and governance. London: Routledge.

Bramwell, B., \& Lane, B. (2000). Tourism collaboration and partnerships: Politics, practice and sustainability. Clevedon: Channell View.

Dredge, D. (1999). Destination place planning and design. Annals of Tourism Research, 26(4), 772-791.

Dredge, D. (2006). Networks, conflict and collaborative communities. Journal of Sustainable Tourism, 14(6), 562-581.

European Union. (2013). European tourism indicator system - Toolkit for sustainable destinations. Brussels: European Commission.

Flagestad, A., \& Hope, C. A. (2001). Strategic success in winter sports destinations: A sustainable value creation perspective. Tourism Management, 22(5), 445-461.

Franzoni, S. (2013). Tourism network: Which governance model and performance tools? Paper presented at the 3rd International Conference on Tourism Management and Tourism Related Issues. Barcelona: Eiasm.

Franzoni, S. (2014). Public governance of welfare services in Italy. In T. Brandsen, W. Trommel, \& B. Verschuere (Eds.), Manufacturing civil society. Principles, practices and effects (pp. 136-158). Hampshire: Palgrave Macmillan.

Franzoni, S. (2015). Measuring the sustainability performance of the tourism sector. Tourism Management Perspectives, 16, 22-27.

Global Reporting Initiative. (2002). Sustainability reporting guidelines - Tour operators'sector supplement. Amsterdam: Global Reporting Initiative.

Hall, C. M., \& Lew, A. A. (1998). Sustainable tourism: A geographical perspective. London: Prentice Hall.

Huxham, C., \& Vangen, S. (2005). Managing to collaborate: The theory and practice of collaborative advantage. London: Routledge.

Kenis, P., \& Provan, K. G. (2009). Towards an exogenous theory of public network performance. Public Administration, 87(3), 440-456.

Kickert, W., Klijn, E. H., \& Koppenjan, J. (2001). Managing complex networks: Strategies for the public sector. London: Sage Publications. 
Klijn, E. H., Steijn, B., \& Edelenbos, J. (2010). The impact of network management on outcomes in governance networks. Public Administration, 88(4), 1063-1082.

Kuik, O., \& Verbruggen, H. (1991). In search of indicators of sustainable development. Dordrecht, Netherlands: Kluwer Academic Publishers.

Laws, E. (1995). Tourist destination management. London: Routledge.

Lemmetyinen, A., \& Go, F. M. (2009). The key capabilities required for managing tourism business networks. Tourism Management, 30(1), 31-40.

Liverman, D. M., Hanson, M. E., Brown, J. B., \& Meredith, R. W. (1988). Global sustainability: Toward measurement. Environmental Management, 12(2), 133-143.

Madanipour, A., Hull, A. D., \& Healey, P. (2001). The governance of place: Space and planning processes. Aldershot: Ashgate.

Manning, T. (1999). Indicators of tourism sustainability. Tourism Management, 20(1), 179-181.

Marsh, J. (1993). An index of tourism sustainability. In J. Nelson, R. Butler, \& G. Wall (Eds.), Tourism and sustainable development: Monitoring, planning, managing (pp. 257-258). Waterloo: Department of Geography, University of Waterloo.

Martini, U. (2005). Management dei sistemi territoriali. Gestione e marketing delle destinazioni turistiche. Torino: Giappichelli Editore.

OECD. (2013). Indicators for measuring competitiveness in tourism. A guidance document. Paris: OECD Publishing.

Osborne, S. P. (2010). The new public governance? Emerging perspectives on the theory and practice of public governance. New York, NY: Routledge.

Paget, E., Dimanche, F., \& Mounet, J. P. (2010). A tourism innovation case: An actor-network approach. Annals of Tourism Research, 37(3), 828-847.

Pavlovich, K. (2003). The evolution and transformation of a tourism destination network: The Waitomo Caves, New Zealand. Tourism Management, 24(4), 203-216.

Provan, K. G., \& Kenis, P. (2008). Modes of network governance: Structure, management, and effectiveness. Journal of Public Administration Research and Theory, 18(2), 229-252.

Provan, K. G., \& Milward, H. B. (2001). Do networks really work? A framework for evaluating public-sector organizational networks. Public Administration Review, 61(4), 414-423.

Rhodes, R. A. W. (2000). The governance narrative: Key findings and lessons from the ESRC's Whitehall Programme. Public Administration, 78(2), 345-363.

Rigall-Torrent, R. (2008). Sustainable development in tourism municipalities: The role of public goods. Tourism Management, 29(5), 883-897.

Rispoli, M., \& Tamma, M. (1995). Le risposte strategiche alla complessità: Le forme di offerta dei prodotti alberghieri. Torino: Giappichelli.

Scott, N., Cooper, C., \& Baggio, R. (2008). Destination networks: Four Australian cases. Annals of Tourism Research, 35(1), 169-188.

Shaw, G., \& Williams, A. M. (2004). Tourism and tourism spaces. London: Sage Publications.

Stabler, M. J. (1997). Tourism \& sustainability: Principles to practice. New York, NY: CAB International.

UNWTO. (2004). Indicators of sustainable development for tourism destination. Madrid: World Tourism Organization.

Vera, J. F., \& Ivars, J. A. (2003). Measuring sustainability in a mass tourist destination: Pressures, perceptions and policy responses in Torrevieja, Spain. Journal of Sustainable Tourism, 11(2-3), 181-203.

Waligo, V. M., Clarke, J., \& Hawkins, R. (2013). Implementing sustainable tourism: A multi-stakeholder involvement management framework. Tourism Management, 36(2), 342-353.

White, V., McCrum, G., Blackstock, K. L., \& Scott, A. (2006). Indicators and sustainable tourism: Literature review. Aberdeen: Macaulay Institute.

World Travel and Tourism Council, World Tourism Organization, \& Earth Council. (1995). Agenda 21 for the travel \& tourism industry: Towards environmentally sustainable development. Geneva: UN Publications. 